Article

\title{
Evaluating Sustainability of Mass Rapid Transit Stations in Dubai
}

\author{
Jaime Larumbe
}

Citation: Larumbe, J. Evaluating Sustainability of Mass Rapid Transit Stations in Dubai. Sustainability 2021, 13, 12965. https://doi.org/10.3390/ su132312965

Academic Editors: Efthimios Bothos, Gabriella Mazzulla, Panagiotis Georgakis, Babis Magoutas and Michiel de Bok

Received: 7 October 2021

Accepted: 19 November 2021

Published: 23 November 2021

Publisher's Note: MDPI stays neutral with regard to jurisdictional claims in published maps and institutional affiliations.

Copyright: (C) 2021 by the author. Licensee MDPI, Basel, Switzerland. This article is an open access article distributed under the terms and conditions of the Creative Commons Attribution (CC BY) license (https:// creativecommons.org/licenses/by/ $4.0 /)$.
Department of Graphic Design and Engineering Projects, University of the Basque Country EHU/UPV, P1 IT Quevedo 1, 48013 Bilbao, Spain; jaime.larumbe@ehu.eus

\begin{abstract}
A transport business that has reached financial sustainability is one that is providing a service at a price that not only covers its costs but also creates a profit for upcoming contingencies. A focus on rail infrastructure financial sustainability is of paramount importance to guarantee the availability of punctual rail transport to remote potential users. To evaluate the sustainability of mass rapid transit on the relation among hypothetical key aspects of sustainability-perception of property; willingness to pay for maintenance, repair, and operations; confidence in the Roads and Transport Authority; and citizen participation in the rail project-and railway service punctuality, the most important result variable, was studied according to the specialized literature on rail transport sustainability. Leading information was collected by means of personal questionnaires of more than 1000 railway users according to the Krejcie Morgan formula for the calculation of the sample size knowing the population size. Qualitative plus quantitative information was gathered from different ways (technical test of the rail system, discussions with users, focus-group discussions, and interviews with key informers).The outputs by means of the statistical analysis allowed understanding two key perceptions. Firstly, beyond a half decade after construction, during a system intervention, a smaller perception of public property for the railway system was related to better service punctuality. This idea contrasts with the vast majority of the publications, which highlight a regular, direct relationship between perception of property and sustainability of railway systems. Secondly, in spite of three-quarters of users accepting that they would contribute monetarily for maintenance, repair, and operations service, such payments were not imminent because of the lack of confidence in the Roads and Transport Authority. In this situation, more than one-third of the metro stations were identified as non-punctual, beyond a half decade after construction.
\end{abstract}

Keywords: sustainability; mass rapid transit stations; perception of property; willingness to pay; Dubai; statistical analysis; discussions with users; focus-group discussions; technical rail assessment; interviews with key informants

\section{Introduction \\ 1.1. Current Situation}

The target 9.1 of the established Sustainable Development Goals is access to reliable and affordable transport networks for all by 2030 [1]. The fulfilment of this target is predicted to address particular challenges in the UAE, which was not able to accomplish all the Millennium Development Goals' sustainable transport network goals [2]. In fact, railway network coverage in the UAE is smaller than expected for a fast developing nation [3]. In the UAE, concretely, only Dubai has access to an enhanced network of mass rapid transit [4].

The benefit of an enhanced railway service in remote regions of fast developing nations has been proven to get to a higher number of sectors than considered in the past [5]. The provision of a rail network is an essential topic for economic and social development [6], which gives citizens the opportunity to generate income and create employment sustainably and save energy [7]. Indeed, if given a monetary value, the 
time non-urban residents consume on the commute to work many times corresponds to the salary rates for non-skilled employment [8]. Several investigations have proven that the time saved from commuting to the job is often invested in an income-generating activity [9-11]. In this regard, some authors state that railway transport increases the ability to travel and with no constraints for women, which is a primary right ensuring employment and equity of admission to public areas, jobs, entertainment, and health care [12,13].

In spite of that, sustainability is a key necessity for railway systems to produce such advantages. The vast majority of the benefits reached by means of improved railway service will be lost if the rail systems have low punctuality [14-16]. In addition, the environmental benefits associated to the use of mass rapid transit from an enhanced station are heavily hindered by delays of the service [17-19]. No relevant benefit to public health goals will be accomplished as long as the mass rapid transit is subject to poor punctuality $[20,21]$. The mere existence of rail infrastructure is not enough for being sustainable [22,23].

Recently, companies responsible for the construction of railway systems have taken huge endeavors to determine the most important indicators of sustainability in mass rapid transit. Sustainability drivers have been pinpointed by many investigations, concentrating on environmental, institutional, social, technical, and financial aspects of the rail stations. In spite of that, an agreed group of drivers has not yet been identified, and the indicators of sustainability fluctuate among companies, projects, and researchers [24-26]. Key drivers of sustainability that have been broadly mentioned include the punctuality of rail stations [27-29], willingness to pay for maintenance, repair, and operations activity [30-32], confidence in the transport authority [33], involvement of the citizens in the construction [34-36], and perception of property of infrastructure [37-39].

Additionally, a huge number of drivers has also been pinpointed. Some authors state that instead of concentrating on rail system accessibility and capacity, higher consideration should be given to continuation by means of mechanisms to enhance maintenance $[40,41]$. Other authors investigated further the technical dimension of the rail system and deduced that the most relevant factors for succeeding in the future are intense citizen participation and sociologically proper promotion [42,43]. Different factors for rail transport sustainability are giving priority to collaboration among private and public companies [44,45]; stressing the financial scope by emphasizing the relevance of users' self-organization, assuming and collecting enough capital to maintain the system without assistance [46,47]; observing the capacity of public rail boards and their impact to guarantee the operation of the transport system in the future [48]; local companies' capacity to coordinate maintenance, repair, and operations practice in an effective way [49]; and raising the strength of community rail boards [50].

Among the variety of indicators of sustainability, perception of belonging of the rail network by users has received special interest. Perception of belonging is explained as the level to which users psychologically observe that the infrastructures belong to them [51]. Some authors state that user perception of property has a fundamental place in the sustainability of the rail system [52]; it is related to users' disposition to contribute to the maintenance of the infrastructure and, in general, absence of passengers' perceptions of property is treated as a risk to sustainability [53].Consequently, an emphasis on rail financial sustainability is especially important to guarantee the availability of punctual rail transport to remote potential users. A transport business that has achieved financial sustainability is one that is selling a service at a price that not only covers its expenses but also creates a profit for upcoming contingencies. One example of community being served by non-punctual mass rapid transit can be found in Dubai. Less than 12 years since construction of the mass rapid transit stations in the city, a lack of punctuality rang serious alarm bells for all stakeholders engaged in the metro. 


\subsection{Purpose of the Research}

The purpose of this study was to identify the most relevant factors affecting the sustainability of seven mass rapid transit stations built in the city and to discover the sources of the fall in punctual rail transport provision. Five essential drivers of sustainability were evaluated from the perspective of the users and the relevant associations among these drivers. The investigation was grounded by data collected from surveys of more than 1000 local residents and a dozen focus group discussions with stakeholders engaged with the rail project.

After this introduction, the study area is presented. After that, the data collection methodology, sample frame, variables, and statistical analysis are identified. The outputs are then described, assessing the correlation of community level factors-perception of property; willingness to pay for maintenance, repair, and operations; confidence in the transport authority; degree of intervention; and citizen participation-with two main results: punctuality of the metro and degree of intervention. A relevant correlation was found among perception of property and punctuality of the system, and among perception of property and degree of intervention. It was also discovered that users' customer reservation price for the maintenance, repair, and operations is hindered by an absence of confidence in the present rail boards. The paper ends with a discussion of the results.

\section{Study Area}

Dubai is the most crowded town in the United Arab Emirates (UAE), and it is the Emirate of Dubai's capital [54].

Placed on the east side of the Arabian Peninsula on the shore of the Persian Gulf, Dubai pursues becoming the commerce center of the Middle East $[55,56]$. Additionally, it is a leading international center for freight and passenger transport [57,58]. Oil earnings supported speeding up the progress of the metropolis, which was already an important mercantile hub [59]. As per the government, the census of the city is 3,400,800 as of 8 September 2020 [60].

Transport in the city is managed by the Roads and Transport Authority (RTA), a state-owned company, founded by royal edict in 2005 [61]. The public transport system has in the past suffered traffic jams and reliability problems, which an important investment plan has faced, in addition to over AED 70 billion of enhancements that were scheduled for fulfilment by 2020, when the population of the metropolis was expected to be more than 3.5 million [62].

Dubai Metro contains two lines (Red line and Green line), which operate along the financial and residential zones of the metropolis, as per Figure 1. It was inaugurated in September 2009 [63]. The UK-based international service company Serco is responsible for operating the metro. The Red Line, which consists of 29 stations (one at ground level, four underground, and 24 elevated) operating from Rashidiya Station to UAE Xchange Station in Jebel Ali, is the most important central line. The Green Line, operating from the Etisalat Station to the Creek Station, contains 20 stations (eight underground, 12 elevated). An extension to the Red Line joining the EXPO 2020 site opened in April 2020. The Blue and Purple lines have also been programmed. The Dubai Metro is the first urban mass rapid transit in the whole Arabian Peninsula [64]. The trains are entirely operated by automation and are driverless. 


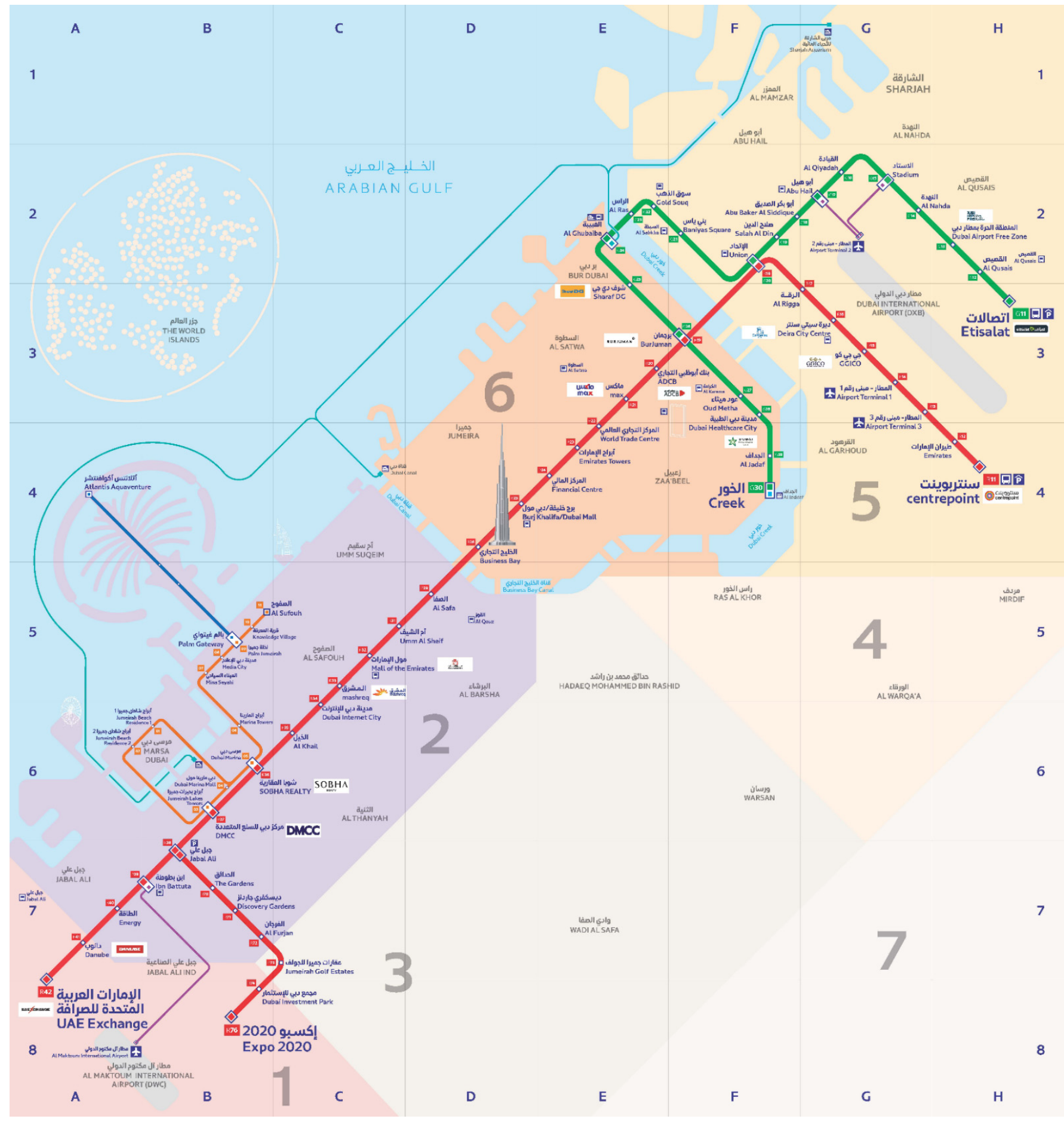

Figure 1. Map of the study area. 


\section{Methods}

\subsection{Data}

Data gathering was carried out throughout the vacation period from July to September in 2018, 2019, and 2020. As the data gatherings were all carried out in summer, there were not seasonal changes. The field work was included in a bigger research project on sustainability of rail stations in the area. Qualitative plus quantitative information was gathered in four different ways:

1. Technical test of the rail system;

2. Discussions with users;

3. Focus-group discussions; and

4. Interviews with key informers.

The technical test of each rail station contained a checklist of topics such as the state and punctuality of the rail lines. This was carried out by two teams of engineers, who supervised 42 stations. The Qualitative information was collected by means of focus-group discussions separated by gender, which were done very early to organize and define the questions contained in the questionnaire. For these debates, contributors were chosen from engaged rail board participants, technicians, and users on behalf of all stakeholders taking part in the project. Altogether, 10 focus-group discussions were carried out, with six to eight participants in each. A thorough analysis of documents was also considered to create the survey questionnaire. The aim of using different methods to collect the same data was the triangulation of the information and enhancement of the reliability and precision of the investigation.

A formal and personal survey was carried out by means of the interview of more than 1000 users at their homes, according to the Equation (1), which is the Krejcie Morgan formula for the calculation of the sample size knowing the population size:

$$
n=\frac{N \cdot z \cdot p \cdot q}{d^{2} \cdot(N-1)+z^{2} \cdot p \cdot q}
$$

where $N$ is the population size, $z$ is the level of trust, $p$ is the chance of success, $q$ is the probability of failure, and $d$ is error.

The survey questionnaire contained closed-ended questions (dichotomous questions, Likert scale multiple questions, rating scale multiple choice questions, checklist-type multiple choice questions, rank order multiple choice) linked to critical predictors of sustainability that are extensively recognized in the specialized publications, covering dimensions related to society, institutions, environment, technology, and finance. Beneficiary users were interviewed about their view about the punctuality of the rail system [65]; their perception of property [66]; their willingness to pay for maintenance, repair, and operations service [67]; their confidence in the transport authority; and their participation in the project [68]. All participants were informed about the goal of the investigation and orally gave their permission. Participants were informed that they were free to finish the interview whenever they wanted to, and they were ensured that the survey would stay anonymous.

Organized interviews were also arranged with key informers at the headquarters of the Roads and Transport Authority (RTA) in Dubai, the major independent government roads and transportation authority in Dubai. These key informers were chosen from technicians responsible for the management and maintenance of the systems, rail board members, and local authorities. Data were reviewed according to degrees of operational and maintenance practice, intervention, managerial activity, user satisfaction, and involvement of stakeholders.

The main purpose of this research work was to analyze the results from the questionnaires. 


\subsection{Sample Frame}

An intentional sampling approach was carried out to monitor the seven mass rapid transit stations that provide rail transport to the different neighborhoods of Dubai. Representation for each population was included for this investigation, while an arbitrary sampling approach was conducted to choose the users from each neighborhood taking part in the surveys. Socio-demographic features of the sample are described in Table 1. Dubai population configuration is the representation of the population described by features such as age, gender, household members, and education level. This characterization is needed to comprehend the social dynamics of Dubai from historical and comparative research. This information will combine economics, sociology, and psychology in the city based on the hypothesis that individuals are affected by one another's behavior.

Table 1. Socio-demographic features of the sample.

\begin{tabular}{|c|c|c|c|c|c|c|}
\hline \multicolumn{4}{|c|}{ Age $(\%)$} & \multicolumn{3}{|c|}{ Gender (\%) } \\
\hline \multicolumn{2}{|c|}{ Under 25} & $26-60$ & Over 60 & Female & \multicolumn{2}{|c|}{ Male } \\
\hline \multicolumn{2}{|c|}{$339(27)$} & $755(60)$ & $141(11)$ & $793(63)$ & 426 & 34) \\
\hline \multicolumn{4}{|c|}{ Number of household members (\%) } & \multicolumn{3}{|c|}{ Education level (\%) } \\
\hline $2-4$ & $5-8$ & $9-12$ & $13-16$ & No formal education & Primary & Secondary \\
\hline 347 (27) & $557(44)$ & $287(23)$ & $36(3)$ & $439(35)$ & $522(41)$ & $271(21)$ \\
\hline
\end{tabular}

\subsection{Variables}

System reliability was evaluated by asking the users about the punctuality of the lines of the metro providing mass rapid transit in Dubai. Responses were classified as very small (non-punctual), small (punctual three times per day), moderate (unpunctual once per day), big (unpunctual once per week), or very big (constantly punctual).

Due to a low cell count, the classifications of big and very big were joined, and, for regression analysis, this variable was dichotomized (punctual $\leq$ three times a day; unpunctual $\leq$ once a day).

Perception of property was evaluated by asking users who they thought was the final owner of the rail network: the citizenship, the constructor private company, the Government, or the stock market. A dichotomous variable was sorted out to illustrate if they thought they were owners or they did not.

Degree of intervention was evaluated by asking key informers and focus-group partakers about the participation of the constructor private company in managing funds for maintenance repair and operation activities. Answers were classified as very small, small, moderate, big, or very big. Key informants and focus group participants worked for the constructor private company somehow.

Willingness to pay for maintenance repair and operations service was evaluated by asking users if they would be willing to periodically contribute to the financing of the maintenance of the metro through a fare raise. Answers were classified as yes, sporadically, or no.

Confidence in the transport authority was a dichotomous variable, evaluated by asking participants if they trusted the boards managing the rail system that provides mass rapid transit in Dubai.

Citizens' participation was evaluated by asking users about their degree of participation when they began being involved in the rail projects. Citizens were involved from the very early stage in order to decide certain aspects of the project such as metro stations, accessibility, and so on. Answers were classified as small (participation since the work force began), moderate (participation since the design phase), or big (participation since the requirements-evaluation phase began). 


\subsection{Statistical Analysis}

A descriptive summary of the perception of users of the rail transport among various metro stations in Dubai is presented in Table 2. In addition, descriptive statistics investigated the weight of sustainability predictors for every rail station studied in Dubai (Table 2). The relation among these features and the two main predictors of sustainability, punctuality of the rail network and the degree of intervention, is presented in Table 3. It was initially checked applying chi-square test according to Equation (2).

$$
x^{2}=\sum_{i=1}^{k} \frac{\left(x_{i}-m_{i}\right)^{2}}{m_{i}}
$$

where $x^{2}$ is the Chi-Square test, $m_{i}$ is the expected value, $x_{i}$ is the observed value, and $i$ is the test number.

Many researchers have demonstrated that punctuality is of paramount importance to rail user satisfaction [69-71]. Punctuality is considered to be one of the most relevant sustainability indicators in railway operations [72-74]. To assist the economic and social development of the regions, rail interventions will promote the safety, competitiveness, duration, and accessibility of rail transport, in part by means of the maintenance of infrastructure and a feasible rail system [75-77].

The correlation of perception of property with the punctuality of the system was firstly assessed applying regression of ordinal logistics, according to Equation (3).

$$
l=\log _{b} \frac{P}{1-P}=\beta_{0}+\beta_{1} \cdot x_{1}+\beta_{2} \cdot x_{2}
$$

where $l$ is the log-odds, $b$ is the base of the logarithm, $p$ is the logistic model predicted probability, $\beta_{i}$ are parameters of the model, and $x_{i}$ are the explanatory variables.

However, the hypothesis of the proportional odds was not maintained in the model of cumulative logit $(p<0.001)$, and the empirical logits visual analysis did not present parallel lines. Because of that plus the sample volume, punctuality of the rail network was dichotomized, and the odds of big system punctuality (unpunctual once a day or less) was predicted between those (1) with no perception of property, (2) who were not willing to pay, (3) who had a moderate to very big degree of intervention, and (4) who did not trust the transport authority. The models were modified for several predictors (OR1 and OR2), as depicted for each disclosure at the end of Table 4.

The SAS 9.4 (SAS Institute, Cary, NC, USA) was used to carry out the data analysis.

\section{Results}

Regarding the punctuality of the rail network, $70 \%$ of interviewees declared it was either never punctual or less than three times a day (Table 2). Around 50\% of the sample had a perception of property of the rail network (Table 2).

There was broad disparity in the understood degree of intervention throughout the midterm after the construction of the metro (5 years after the construction phase) along the rail stations (Table 2). After the construction of the rail network, the Mashreq station had not received intervention from any agent and the Danube and Burjuman stations had received assistance from the rail private companies sporadically. Healthcare Center station was inaugurated in 2010 to offer reliable rail transport to get to the hospital and its neighboring areas. From that moment onwards, the rail private companies sporadically provided further assistance in the maintenance activity. Union rail station was opened in 2010. After a few years of unpunctuality, the station was taken by the local private company to re-organize the rail committee and assist the operation and maintenance practice. Al Jadaf and Burj Khalifa both benefit from regular assistance of maintenance and operations from the constructor. Five of the rail stations investigated were opened 10 years before the 
research, while the Burj Khalifa station was opened 6 years prior to the investigation kickoff (Table 2). This information was gathered in different ways (technical test of the rail system, discussions with users, focus-group discussions, and interviews with key informers).

Punctuality fluctuates not only from one station to another but also among lines within the same station (Table 2). In Mashreq and Burjuman, a big percentage of the citizens stated that the enhanced rail service was always unpunctual, while in Al Jadaf and Healthcare Center, most experienced punctual rail service at least three times per day (Table 2). In Burj Khalifa, most of the users experienced punctual rail service on a daily basis. Fewer participants in Danube had daily access to punctual rail service, while just under $30 \%$ of participants depicted either punctual service just three times per day or unpunctual rail transport service (Table 2).

Fifty percent of the participants thought that the citizens were owners of the rail system. In Danube, Mashreq, and Burjuman, a big portion of participants revealed a perception of ownership of the rail system, while in Union, Al Jadaf, and Burj Khalifa, a relevant percentage of participants thought that the system was owned by the private constructor (Table 2). In Healthcare Center, just below 30\% of participants thought that the transport authority owned the rail network, while almost $50 \%$ thought that ownership was with the investment fund.

There was a strong indirect relation among perception of property and degree of intervention (Pearson coefficient of correlation $-0.66 ; p<10^{-4}$; results not pinpointed); that is, rail users who declared a bigger perception of property for their rail service were less likely to use a station that usually had intervention giving managerial assistance to the system. There was no proof of more than a low correlation between the other indicators of sustainability incorporated in the examinations.

Table 3 depicts a relevant correlation among perception of property $\left(p<10^{-4}\right)$, confidence in the transport authority $\left(p<10^{-4}\right)$, degree of the interventions $\left(p<10^{-4}\right)$, and willingness to pay and the punctuality of the rail system. While $60 \%$ of participants with a perception of property declared very low system punctuality (non-punctual), a similar percentage of those with no perception of property reported small or moderate system punctuality. Other factors related to very small or small punctuality of the rail system involved a willingness to pay, no confidence in the transport authority, and experiencing lower numbers of interventions (Table 3).

There was also a relevant relation of perception of property $\left(p<10^{-4}\right)$, willingness to pay $\left(p<10^{-4}\right)$, and confidence in the transport authority $\left(p<10^{-4}\right)$ with the degree of intervention (Table 3). Around $85 \%$ of those with no perception of property reported a moderate to very big degree of intervention, and an analogous percentage of those with a perception of property declared a very small or small degree of intervention (Table 3). Those who were not willing to pay and who mistrusted the transport authority tended to experience a smaller degree of intervention (Table 3).

Outputs from logistic regression models depict that those with no perception of property had bigger odds of high rail system punctuality (unadjusted OR 1.83: 95\% C.I. $1.43,2.35$, Table 4). Despite that, this estimate was reduced and became statistically not significant after adjusting for the degree of intervention (Table 4, OR1).

In comparison with those who were willing to pay for the rail network, those who were willing to do it sporadically (unadjusted OR 6.49: 4.61,9.14) or not at all (unadjusted OR 3.38: 2.16, 5.28) had raised odds of moderate to very big network punctuality, even after adjusting for degree of confidence in the transport authority and degree of citizen participation. A moderate to very big degree of intervention was also strongly related with increased odds of big system punctuality (unadjusted OR 2.27: 1.76, 2.93). Those who mistrusted the transport authority had smaller odds of moderate to very big network punctuality (unadjusted OR 0.13: 0.10, 0.17) (Table 4). 
Table 2. Perception of users of the rail transport service among various metro stations in Dubai. Descriptive summary.

\begin{tabular}{|c|c|c|c|c|c|c|c|c|c|c|c|c|c|}
\hline \multicolumn{5}{|c|}{ General Data } & \multicolumn{6}{|c|}{ Punctuality of the Train } & \multicolumn{3}{|c|}{ Perception of Property } \\
\hline $\begin{array}{l}\text { Metro } \\
\text { station }\end{array}$ & $\begin{array}{c}\text { Year } \\
\text { completed }\end{array}$ & $\begin{array}{l}\text { Number } \\
\text { of lines }\end{array}$ & $\begin{array}{c}\text { Total } N=1253 \\
* n(\%)\end{array}$ & $\begin{array}{l}\text { Degree of } \\
\text { intervention }\end{array}$ & $\begin{array}{l}\text { Always } \\
\text { punctual } n \\
=69(6 \%)\end{array}$ & $\begin{array}{c}\text { Unpunctual } \\
\text { once per } \\
\text { week } n=33 \\
(2 \%)\end{array}$ & $\begin{array}{c}\text { Unpunctual } \\
\text { once per } \\
\text { day } n=274 \\
(22 \%)\end{array}$ & $\begin{array}{c}\text { Punctual } \\
\text { three times } \\
\text { per day } n= \\
352(28 \%)\end{array}$ & $\begin{array}{c}\quad \text { Never } \\
\text { punctual } n \\
=523(28 \%)\end{array}$ & $\begin{array}{c}\text { Government } \\
n=121 \\
(10 \%)\end{array}$ & $\begin{array}{c}\text { Citizens } n= \\
618(50 \%)\end{array}$ & $\begin{array}{l}\text { Investment } \\
\text { fund } n=74 \\
\quad(6 \%)\end{array}$ & $\begin{array}{c}\text { Private } \\
\text { company } n \\
=430(34 \%)\end{array}$ \\
\hline Al Jadaf & 2014 & 1 & 150 (12) & Very big & $8(5)$ & $3(2)$ & $47(31)$ & $90(60)$ & $2(1)$ & $33(22)$ & $6(4)$ & $3(2)$ & $108(72)$ \\
\hline Danube & 2012 & 1 & 210 (17) & Small & $3(1)$ & $1(0)$ & 87 (41) & 57 (27) & $62(30)$ & $4(2)$ & 204 (98) & $0(0)$ & $1(0)$ \\
\hline Burjuman & 2010 & 2 & 211 (17) & Small & $12(6)$ & $3(1)$ & $23(11)$ & $42(20)$ & 131 (62) & $16(8)$ & $138(66)$ & $5(2)$ & $49(24)$ \\
\hline Union & 2010 & 2 & 203 (17) & $\mathrm{Big}$ & $21(10)$ & $5(2)$ & $19(9)$ & 67 (33) & 91 (45) & $8(4)$ & 73 (36) & $3(1)$ & $119(59)$ \\
\hline Burj Khalifa & 2010 & 1 & 150 (12) & Very big & $24(16)$ & $21(14)$ & $79(53)$ & $21(14)$ & $4(3)$ & $22(15)$ & $9(6)$ & $5(3)$ & $110(75)$ \\
\hline $\begin{array}{l}\text { Healthcare } \\
\text { Center }\end{array}$ & 2010 & 1 & $118(9)$ & Moderate & $1(1)$ & 0 & $13(11)$ & $69(58)$ & $34(29)$ & $34(29)$ & $6(5)$ & $55(47)$ & $21(18)$ \\
\hline \multicolumn{5}{|c|}{ General data } & \multicolumn{6}{|c|}{ Willingness to pay } & \multicolumn{3}{|c|}{ Confidence in transport authority } \\
\hline & $\begin{array}{c}\text { Year } \\
\text { completed }\end{array}$ & Num & ber of lines & $\begin{array}{c}\text { Degree of } \\
\text { intervention }\end{array}$ & \multicolumn{2}{|c|}{ Yes $n=950(77 \%)$} & Sporadically & $=191(16 \%)$ & \multicolumn{2}{|c|}{ No $n=91(7 \%)$} & $\begin{array}{l}\text { Yes } n=350 \\
\quad(28 \%) \mathrm{s}\end{array}$ & $\begin{array}{l}\text { Uncertain } n \\
=23(2 \%)\end{array}$ & $\begin{array}{c}\text { No } n=871 \\
\quad(28 \%)\end{array}$ \\
\hline Al Jadaf & 2014 & & 1 & Very big & \multirow{2}{*}{\multicolumn{2}{|c|}{$47(31)$}} & 90 & & \multicolumn{2}{|c|}{$15(7)$} & $33(22)$ & $6(4)$ & 108 (72) \\
\hline Danube & 2012 & & 1 & Small & & & 57 & & \multicolumn{2}{|c|}{$10(5)$} & $4(2)$ & $204(98)$ & $1(0)$ \\
\hline Burjuman & 2010 & & 2 & Small & \multicolumn{2}{|c|}{$\begin{array}{l}87(41) \\
23(11)\end{array}$} & 42 & & \multicolumn{2}{|c|}{$21(14)$} & $16(8$ & $138(66)$ & $49(24)$ \\
\hline Union & 2010 & & 2 & Big & \multicolumn{2}{|c|}{$19(9)$} & 67 & & \multicolumn{2}{|c|}{$9(13)$} & $8(4)$ & $73(36)$ & $119(59)$ \\
\hline Mashreq & 2010 & & 1 & Very low & \multicolumn{2}{|c|}{$6(3)$} & & & \multicolumn{2}{|c|}{$\begin{array}{l}10(9) \\
7(3)\end{array}$} & $4(2)$ & $182(86)$ & $22(10)$ \\
\hline $\begin{array}{l}\text { Healthcare } \\
\text { Center }\end{array}$ & 2010 & & 1 & Moderate & \multicolumn{2}{|c|}{$13(11)$} & 69 & & \multicolumn{2}{|c|}{$34(29)$} & $34(29$ & $6(5)$ & $21(18)$ \\
\hline
\end{tabular}

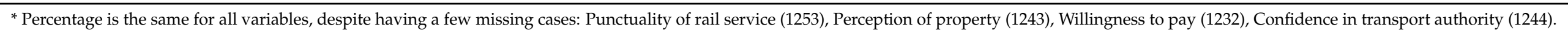


Table 3. Relation among citizenship factors with the degree of intervention and the punctuality of the service.

\begin{tabular}{|c|c|c|c|c|c|c|c|c|c|c|c|c|}
\hline \multicolumn{8}{|c|}{ Degree of Intervention } & \multicolumn{5}{|c|}{ Punctuality of the Service } \\
\hline & & $\%$ & $\begin{array}{l}\text { Very small } \\
(16.8 \%)\end{array}$ & Small $(33.6 \%)$ & $\begin{array}{l}\text { Moderate to } \\
\text { big }(25.6 \%)\end{array}$ & $\begin{array}{l}\text { Very big } \\
(23.9 \%)\end{array}$ & p-value & $\begin{array}{c}\text { Very small } \\
\text { (Unpunctual) } \\
(41.9 \%)\end{array}$ & Small $(28.1 \%)$ & $\begin{array}{l}\text { Moderate } \\
(21.8 \%)\end{array}$ & $\begin{array}{c}\text { Big to very big } \\
(8.2 \%)\end{array}$ & $p$-value \\
\hline Citizen participation & & & & & & & $0.45 *$ & & & & & 0.077 \\
\hline Small & 82.0 & & 15.8 & 33.9 & 26.1 & 24.2 & & 42.7 & 28.1 & 20.8 & 8.3 & \\
\hline Moderate & 11.1 & & 35.8 & 18.3 & 25.6 & 20.4 & & 45.3 & 24.8 & 23.4 & 6.6 & \\
\hline Big & 6.9 & & 1.2 & 53.5 & 22.1 & 23.3 & & 26.7 & 33.7 & 31.4 & 8.1 & \\
\hline $\begin{array}{l}\text { Confidence in the } \\
\text { transport authority }\end{array}$ & & & & & & & $<0.0001$ & & & & & $<0.0001$ \\
\hline Yes & 29.2 & & 5.8 & 39.0 & 14.5 & 40.7 & & 14.5 & 24.8 & 47.1 & 13.7 & \\
\hline No & 70.8 & & 21.8 & 31.7 & 30.3 & 16.2 & & 53.6 & 29.5 & 11.0 & 5.9 & \\
\hline Perception of property & & & & & & & $<0.0001$ & & & & & $<0.0001$ \\
\hline Yes & 49.8 & & 29.4 & 55.4 & 12.8 & 2.4 & & 57.7 & 18.9 & 18.9 & 4.5 & \\
\hline No & 50.2 & & 4.6 & 12.0 & 38.4 & 45.0 & & 26.2 & 37.5 & 24.8 & 11.5 & \\
\hline Degree of intervention & & & & & & & & & & & & $<0.0001$ * \\
\hline Very small & 16.9 & & & & & & & 94.3 & 2.8 & 2.8 & 0 & \\
\hline Small & 33.6 & & & & & & & 45.9 & 23.5 & 26.1 & 4.5 & \\
\hline Moderate-Big & 25.6 & & & & & & & 39.2 & 42.4 & 10.0 & 8.4 & \\
\hline Willingness to pay & & & & & & & $<0.0001$ & & & & & $<0.0001$ \\
\hline Yes & 77.1 & & 20.6 & 39.8 & 27.1 & 12.5 & & 49.7 & 28.8 & 14.0 & 7.5 & \\
\hline Sporadically & 15.5 & & 4.2 & 4.7 & 20.4 & 70.7 & & 13.1 & 13.6 & 52.9 & 10.5 & \\
\hline No & 7.4 & & 7.7 & 27.5 & 20.9 & 43.9 & & 22.0 & 29.7 & 39.6 & 8.8 & \\
\hline
\end{tabular}


Table 4. Relation among of degree of intervention, perception of property, confidence in the transport authority, and willingness to pay with punctuality of the rail system.

\begin{tabular}{|c|c|c|c|c|c|c|c|c|}
\hline \multicolumn{9}{|c|}{ Punctuality of the Railway System } \\
\hline \multicolumn{8}{|c|}{ Moderate to very big (delay $\leq$ once per day) $30 \%$} & $\begin{array}{l}\text { Very small to } \\
\text { small (punctual } \\
\leq \text { three times } \\
\text { per day) }\end{array}$ \\
\hline Principal disclosure & $\%$ & $95 \% C I$ & OR2 & $95 \% \mathrm{CI}$ & OR1 & $95 \% \mathrm{CI}$ & $\begin{array}{c}\text { Non-adjusted } \\
\text { OR }\end{array}$ & Ref. \\
\hline $\begin{array}{l}\text { Degree of intervention } \\
\text { Moderate to very big }\end{array}$ & 49.6 & $0.97,2.23$ & 1.47 & $1.51,3.03$ & 2.14 & $1.76,2.93$ & 2.27 & 1.0 \\
\hline $\begin{array}{c}\text { Perception of property } \mathrm{b} \\
\text { No } \\
\text { Confidence in the } \\
\text { transport authority }\end{array}$ & 50.2 & $0.66,1.51$ & 0.99 & $0.77,1.54$ & 1.09 & $1.43,2.35$ & 1.83 & 1.0 \\
\hline Willingness to pay $\mathrm{d}$ & 70.8 & & & & & $0.10,0.17$ & 0.13 & 1.0 \\
\hline No & 7.4 & $2.05,5.51$ & 3.36 & $2.09,5.6$ & 3.42 & $2.16,5.28$ & 3.38 & 1.0 \\
\hline Sporadically & 15.5 & $3.54,7.54$ & 5.17 & $3.54,7.54$ & 5.17 & $4.61,9.14$ & 6.49 & 1.0 \\
\hline
\end{tabular}

$95 \%$ confidence intervals and odds ratio from logistic regression models are depicted (bolded values are relevant at the degree of $p<0.005$ ). Unadjusted estimates are from bivariate regression analyses, while variables considered in OR1 and OR2 are presented in the table footnotes; a degree of intervention (ref. = very small to small): OR1, adjusted for perception of property; OR2, OR1 + adjusted for confidence in transport authority and willingness to pay; ${ }^{\mathrm{b}}$ Perception of property (ref. = yes): OR1, adjusted for degree of intervention; OR2, OR1 + confidence in the transport authority, willingness to pay; ${ }^{\mathrm{C}}$ Confidence in the transport authority (reference $=$ yes). No adjustment for confounding; ${ }^{\mathrm{d}}$ Willingness to pay (ref. = yes): OR1, adjusted for confidence in the transport authority; OR2, OR1 + degree of citizen participation.

\section{Discussion}

In Dubai, the interventions experienced by some rail stations have concentrated on enhancing punctuality of the systems and arranging financial management for them; so, the punctuality of the rail network open to interventions has improved notably. In spite of that, the sporadic interventions have been associated with a non-predicted output: The rail stations susceptible to interventions have lower perceptions of property by the citizenship. This highlights a risk to the sustainability in the future if forthcoming usual interventions are not ensured.

Relevant relationships of perception of property with punctuality of the system and perception of property with degree of interventions (Table 3) pinpoint that the nature of the association among perception of property and punctuality is caused by the degree of the interventions. In the midterm after the construction, most of the rail station users with a perception of property disclosed a very small or a small degree of interventions and very low system punctuality. The other way around, users with no perception of property declared moderate to very big degrees of interventions and small or moderate system punctuality. These outputs should be considered within a different perception as to how a perception of property is related to punctuality in the long term [69]. This research shows that, under concrete types of interventions, better network punctuality of rail stations can be related to a smaller perception of property. This is in conflict with the widely agreed perception of a direct connection among sustainability and perception of property that some publications mention [78-80].

Likewise, in order to manage rail stations, when willing to set expenses and recovery policy to finance long-term rail operation, it is relevant to evaluate a citizenship's willingness to pay for the enhancement of the service. Some authors relate a citizenship's willingness to pay with the request of an enhanced service as a tester of the capacity to obtain sustainable networks [32,81]. In this investigation, the declared willingness to pay in Dubai (Table 2) is an obvious indication of the citizens' concern in enhancing the network. This orientation, however, is not supported by confidence in the transport au- 
thority (Table 3). Qualitative information revealed that station users' lack of confidence in the transport authority transforms into users' being hesitant to contribute with regular payments. The amount provided by the monthly instalment of all users is expected to be saved by a reliable treasurer. However, such a position does not exist currently since most of the users mistrust the transport authorities. It is worth saying that the present rail board members were chosen in the construction kickoff, but no public review of organizational objectives has been done since then.

Another important indicator of sustainability is citizen participation in making decisions [82], but not all kinds of participation improve sustainability in the same form [83]. Some authors stated that just citizenship participation in management-related decisions is tightly related with sustainability [44]. Doing a deeper analysis of the outputs obtained from the investigation, the kind of involvement that citizens carried out was evaluated (Table 3). More than three-quarters of the users just began to take part in the construction, when the main decisions were already made. Such outputs demonstrate that not enough efforts were made to involve the citizenship from the early planning phases of the project, constraining citizens' capability for management-related decision making.

The limitation of evaluating the external reliability of the outputs by doing a comparison of the distribution of several predictors of sustainability in other comparable populations has to be admitted. The next investigations will be capable of taking advantage of the outputs of this investigation to verify such validity.

\section{Conclusions}

This investigation revealed two key ideas of widely implemented sustainability testers.

Firstly, a half decade after construction, users have a small perception of property of the rail network with big service punctuality and a big perception of property for railway network with small service punctuality. Interventions in the enhancement of the system punctuality of the stations lower the perception of property in the rail network. The direct relationship among sustainability and the perception of property regularly published has constraints that should be researched more deeply. Rail committees should create a bigger perception of property in the citizenship for those stations susceptible to interventions to achieve sustainability in the future.

Secondly, in Dubai, despite the existence of a deep willingness to pay for the enhancement of rail network, a lack of confidence in the transport authority makes users hesitant to contribute with regular payments to bear the expenses of maintenance service, with the future operation of the rail stations at risk. While perception of property is fairly developed, this sense does not bring the ability of the citizenship to support the management of rail stations. Citizens have not proved capable to arrange referendums for new rail boards or mechanisms to enhance the rail system's management in spite of not trusting the previous rail board, which was elected at the project kickoff.

Rail authorities trying to offer sustainable accessibility to reliable punctual rail service in urban environments can notice from this investigation that the output forecasted from key testers of sustainability such as 'perception of property' and 'willingness to pay' can be strongly hindered by the existence of contradictory predictors. In fact, perception of property is notably sensitive to the impact of interventions, while the influence of users' willingness to pay for the service can be enormously hampered by an absence of confidence in rail boards.

The interventions to improve the rail infrastructure should be properly explained to the public in order to avoid reducing the sense of ownership, which is an important indicator to reach long-term sustainability. Likewise, the rail boards should focus on improving the perception the citizen have about them, offering transparency in their management in order to increase public willingness to pay and, hence, achieve the much needed sustainability in the future.

Funding: This research received no external or internal funding. 
Institutional Review Board Statement: The research was conducted according to the guidelines of the Declaration of Helsinki and approved by RTA Ethics Committee on 12 November 2020.

Informed Consent Statement: Informed consent was obtained from all subjects involved in the research.

Data Availability Statement: The data presented in this research are available on request from the corresponding author.

Acknowledgments: The author would like to thank the RTA Authorities in the person of Mattar Al Tayer for supporting the work reported above. The findings and conclusions expressed in this paper, though, represent exclusively those of the author.

Conflicts of Interest: The author declares no conflict of interests.

\section{References}

1. Mohamad Taghvaee, V.; Assari Arani, A.; Nodehi, M.; Khodaparast Shirazi, J.; Agheli, L.; Neshat Ghojogh, H.M.; Salehnia, N.; Mirzaee, A.; Taheri, S.; Mohammadi Saber, R.; et al. Sustainable development goals: Transportation, health and public policy. Rev. Econ. Political Sci. 2021. [CrossRef]

2. Jha, S.S.; Tandon, D.J.K. A Study on the Impact of Transport and Power Infrastructure Development on the Economic Growth of United Arab Emirates (UAE); Social Science Research Network: Rochester, NY, USA, 2019; SSRN Scholarly Paper ID 3525398. Available online: https:/ / papers.ssrn.com/abstract=3525398 (accessed on 29 September 2021).

3. Worku, G.B. Demand for Improved Public Transport Services in the UAE: A Contingent Valuation Study in Dubai. Int. J. Bus. Manag. 2013, 8, 108. [CrossRef]

4. Designing Guidelines for Metro Stations in Developing Countries: The Case of Dubai. Available online: https://www.jstage.jst. go.jp/article/irspsd/7/4/7_83/_article/-char/ja/ (accessed on 29 September 2021).

5. Vickerman, R. Can high-speed rail have a transformative effect on the economy? Transp. Policy 2018, 62, 31-37. [CrossRef]

6. Ferbrache, F.; Knowles, R.D. City boosterism and place-making with light rail transit: A critical review of light rail impacts on city image and quality. Geoforum 2017, 80, 103-113. [CrossRef]

7. Dolinayova, A.; Kanis, J.; Loch, M. Social and Economic Efficiency of Operation Dependent and Independent Traction in Rail Freight. Procedia Eng. 2016, 134, 187-195. [CrossRef]

8. Swann, A. The Human Workplace: People-Centred Organizational Development; Kogan Page Publishers: London, UK, 2017.

9. Szabó, N.; Farkas, R.; Varga, A. The economic effects of passenger transport infrastructure investments in lagging regions. Would the increase in commuting be beneficial for regional development? Growth Chang. 2021. [CrossRef]

10. Whittington, D.; Cook, J. Valuing Changes in Time Use in Low- and Middle-Income Countries. J. Benefit-Cost Anal. 2019, 10, 51-72. [CrossRef]

11. Abulibdeh, A. Planning for Congestion Pricing Policies in the Middle East: Public Acceptability and Revenue Distribution. Transp. Lett. 2020, 80, 7. [CrossRef]

12. U.I.C. Communications. Women and Transport: An Opportunity for the Industry and for New Forms of Mobility, by Catherine Trautmann. Available online: https://uic.org/com/enews/nr/637/article/women-and-transport-an-opportunity-for-theindustry-and-for-new-forms-of (accessed on 29 September 2021).

13. Ishay, M.R. The Levant Express: The Arab Uprisings, Human Rights, and the Future of the Middle East; Yale University Press: London, UK, 2019.

14. Grechi, D.; Maggi, E. The importance of punctuality in rail transport investigation on the delay determinants. Eur. Transp. 2018, 70, 2.

15. Liu, Y.; Chen, J.; Wu, W.; Ye, J. Typical Combined Travel Mode Choice Utility Model in Multimodal Transportation Network. Sustainability 2019, 11, 549. [CrossRef]

16. Grzelak, M.; Borucka, A.; Świderski, A. Assessment of the influence of selected factors on the punctuality of an urban transport fleet. Transp. Probl. 2020, 15, 4. [CrossRef]

17. Ibrahim, A.N.H.; Borhan, M.N.; Yusoff, N.I.M.; Ismail, A. Rail-based Public Transport Service Quality and User Satisfaction-A Literature Review. Promet-Traffic Transp. 2020, 32, 423-425. [CrossRef]

18. Ha, S.; Ibrahim, W.H.W.; Lo, M.C.; Mah, D. Factors Affecting Satisfaction and Loyalty in Public Transport using Partial Least Squares Structural Equation Modeling (PLS-SEM). Transport 2019, 10, 60. [CrossRef]

19. Soltani, S. Investigating the Effect of Trackwork on Punctuality of Swedish Railways 2019. Available online: https://ntnuopen ntnu.no/ntnu-xmlui/handle/11250/2632047 (accessed on 29 September 2021).

20. Choudhary, A.; Kumar, P.; Shukla, A.; Joshi, P.K. Urban Mobility Associated Ambient Air Quality and Policies for Environmental Implications. In Air Pollution and Its Complications: From the Regional to the Global Scale; Tiwari, S., Saxena, P., Eds.; Springer International Publishing: Berlin/Heidelberg, Germany, 2021; pp. 163-175. [CrossRef]

21. Guo, Y.; He, S.Y. He Built environment effects on the integration of dockless bike-sharing and the metro. Transp. Res. Part D Transp. Environ. 2020, 83, 102335. [CrossRef] 
22. Palmqvist, C.-W.; Olsson, N.; Hiselius, L. Punctuality Problems from the Perspective of Timetable Planners in Sweden Presented at the 20th EURO Working Group on Transportation Meeting, September 2017. Available online: https: / / portal.research.lu.se/portal/en/publications/punctuality-problems-from-the-perspective-of-timetable-planners-insweden(a6615457-f889-45b2-b6c2-81dded8e6071).html (accessed on 29 September 2021).

23. Stachyra, R.; Roman, K. Analysis of Accessibility of Public Transport in Warsaw in the Opinion of Users. Postmod. Open. 2021, 12, 3. [CrossRef]

24. Tian, N.; Tang, S.; Che, A.; Wu, P. Measuring regional transport sustainability using super-efficiency SBM-DEA with weighting preference. J. Clean. Prod. 2020, 242, 118474. [CrossRef]

25. Guo, B.; Ke, J. The Impacts of High-speed Rail on Sustainable Economic Development: Evidence from the Central Part of China. Sustainability 2020, 12, 2410. [CrossRef]

26. To, W.M.; Lee, P.K.C.; Yu, B.T.W. Sustainability assessment of an urban rail system-The case of Hong Kong. J. Clean. Prod. 2020, 253, 119961. [CrossRef]

27. Djordjević, B.; Mane, A.S.; Krmac, E. Analysis of dependency and importance of key indicators for railway sustainability monitoring: A new integrated approach with DEA and Pearson correlation. Res. Transp. Bus. Manag. 2021, 100650. [CrossRef]

28. di Dottorato, T.D. Sustainability in Passenger Transport: The Relevance of Punctuality in Rail and Modal Choice in Commuting; Dipartimento di Economia-Varese: Pisa, Italy, 2015; p. 140.

29. Rao, S.-H. Transportation synthetic sustainability indices: A case of Taiwan intercity railway transport. Ecol. Indic. 2021, 127, 107753. [CrossRef]

30. Grau, J.M.S.; Konstantinidou, M.; Boufidis, N.; Aifandopoulou, G. Estimation of value-of-time and a comparison of an ex ante and an ex post willingness to pay for shared transport services in Thessaloniki. Res. Transp. Econ. 2021, 101092. [CrossRef]

31. Shi, X.; Ye, Z.; Shiwakoti, N.; Li, H. Passengers' Perceptions of Security Check in Metro Stations. Sustainability 2019, 11, 2930. [CrossRef]

32. Pujiati, A.; Nihayah, D.M.; Bowo, P.A.; Prastiwi, F.S. Willingness to Pay for Improving the Quality of Public Transportation. JEJAK J. Ekon. Dan Kebijak. 2019, 12, 302. [CrossRef]

33. Hamiduddin, I.; Adelfio, M. Social sustainability and new neighbourhoods: Case studies from Spain and Germany. In Urban Social Sustainability; Routledge: London, UK, 2019.

34. Yang, L.; van Dam, K.H.; Zhang, L. Developing Goals and Indicators for the Design of Sustainable and Integrated Transport Infrastructure and Urban Spaces. Sustainability 2020, 12, 9677. [CrossRef]

35. Case study of the Behavioural Intentions of Public Transportation Passengers in Kuala Lumpur-ScienceDirect. Available online: https:/ / www.sciencedirect.com/science/article/pii/S2213624X18300051 (accessed on 30 September 2021).

36. Cruz, R.; Jardim, J.; Mira, J.; Teixeira, C. Smart Rail for Smart Mobility. In Proceedings of the 2018 16th International Conference on Intelligent Transportation Systems Telecommunications (ITST), Lisbon, Portugal, 15-17 October 2018; pp. 1-7. [CrossRef]

37. Knop, L.; Kramarz, M. Attractiveness of the Region in Connection with Intermodal Transport Development. In Sustainable Logistics and Production in Industry 4.0: New Opportunities and Challenges; Grzybowska, K., Awasthi, A., Sawhney, R., Eds.; Springer International Publishing: Berlin/Heidelberg, Germany, 2020; pp. 197-217. [CrossRef]

38. Masoumi, H.E. A discrete choice analysis of transport mode choice causality and perceived barriers of sustainable mobility in the MENA region. Transp. Policy 2019, 79, 37-53. [CrossRef]

39. Nag, D.; Bs, M.; Goswami, A.; Bharule, S. Framework for Public Transport Integration at Railway Stations and Its Implications for Quality of Life. Soc. Sci. Res. Netw. 2019. [CrossRef]

40. Mohammadi, A.; Elsaid, F.; Amador-Jiminez, L. Optimizing transit maintenance and rehabilitation to support human development and sustainability: A case study of Costa Rica's railroad network. Int. J. Sustain. Transp. 2019, 13, 497-510. [CrossRef]

41. Bayane, B.M.; Yanjun, Q.; Bekhzad, Y.; Bayane, B.M.; Yanjun, Q.; Bekhzad, Y.A. review and analysis of railway transportation system in the economic community of West African States: Towards the development of sustainable regional goal. Glob. J. Eng. Technol. Adv. 2020, 2, 4. [CrossRef]

42. Wang, J.; Sekei, V.S.; Ganiyu, S.A.; Makwetta, J.J. Research on the Sustainability of the Standard Gauge Railway Construction Project in Tanzania. Sustainability 2020, 13, 5271. [CrossRef]

43. McNally, A.D. A Tiered Approach for Evaluating the Sustainability of Remediation Activities at Rail Sites. In Proceedings of the 2018 Joint Rail Conference, Pittsburgh, PA, USA, 18-20 April 2018. [CrossRef]

44. Cheng, Z.; Wang, H.; Xiong, W.; Zhu, D.; Cheng, L. Public-private partnership as a driver of sustainable development: Toward a conceptual framework of sustainability-oriented PPP. Environ. Dev. Sustain. 2021, 23, 1043-1063. [CrossRef]

45. Faulin, J.; Grasman, S.E.; Juan, A.A.; Hirsch, P. Chapter 1-Sustainable Transportation: Concepts and Current Practices. In Sustainable Transportation and Smart Logistics; Faulin, J., Grasman, S.E., Juan, A.A., Hirsch, P., Eds.; Elsevier: Amsterdam, The Netherlands, 2019; pp. 3-23. [CrossRef]

46. Mulley, C.; Ho, C.; Balbontin, C.; Hensher, D.; Stevens, L.; Nelson, J.D.; Wright, S. Mobility as a service in community transport in Australia: Can it provide a sustainable future? Transp. Res. Part Policy Pract. 2020, 131, 107-122. [CrossRef]

47. Yusoff, I.; Ng, B.-K.; Azizan, S.A. Towards sustainable transport policy framework: A rail-based transit system in Klang Valley, Malaysia. PLoS ONE 2021, 16, e0248519. [CrossRef]

48. Qiu, W.; Liu, Y.; Lu, F.; Huang, G. Establishing a sustainable evaluation indicator system for railway tunnel in China. J. Clean. Prod. 2020, 268, 122150. [CrossRef] 
49. Azzouz, L.; Jack, A. Benchmarking the sustainability reporting of high-speed railways (HSRs): Towards a state-of-the-art benchmarking and reporting framework for HSRs. J. Clean. Prod. 2020, 250, 119505. [CrossRef]

50. Gharehbaghi, K.; McManus, K.; Hurst, N.; Robson, K.; Myers, M. Complexities in mega rail transportation projects: “Sydney metro" and "Melbourne metro rail" insight. J. Eng. Des. Technol. 2019, 18, 973-990. [CrossRef]

51. Jomnonkwao, S.; Champahom, T.; Ratanavaraha, V. Methodologies for Determining the Service Quality of the Intercity Rail Service Based on Users' Perceptions and Expectations in Thailand. Sustainability 2020, 12, 4259. [CrossRef]

52. Obsie, A.; Woldeamanuel, M.; Woldetensae, B. Service Quality of Addis Ababa Light Rail Transit: Passengers' Views and Perspectives. Urban Rail Transit. 2020, 6, 231-243. [CrossRef]

53. Killen, A. Mitigating Rail Vandalism Through Design Intervention. In Advancing a Design Approach to Enriching Public Mobility; Coxon, S., Napper, R., Eds.; Springer International Publishing: Berlin/Heidelberg, Germany, 2021; pp. 229-247. [CrossRef]

54. Califano, G.; Spinks, D. United Arab Emirates (Dubai). In Adopting Agile Across Borders: A Guide to Navigating Cultural Complexity in Agile Teams and Organizations; Califano, G., Spinks, D., Eds.; Apress: Berkeley, CA, USA, 2021; pp. 217-222. [CrossRef]

55. Gugler, P.; Alburai, M.; Stalder, L. Smart City Strategy of Dubai; Havard Business School: Boston, MA, USA, $2021 ;$ p. 27.

56. Elhacham, E.; Alpert, P. Temperature patterns along an arid coastline experiencing extreme and rapid urbanization, case study: Dubai. Sci. Total Environ. 2021, 784, 147168. [CrossRef] [PubMed]

57. Akila, H.W.; Faleel, J. The race to become the hub of islamic finance. PalArchs. J. Archaeol. Egypt Egyptol. $2021,18,13$.

58. Zhou, Y.; Kundu, T.; Goh, M.; Sheu, J.-B. Multimodal transportation network centrality analysis for Belt and Road Initiative. Transp. Res. Part E Logist. Transp. Rev. 2021, 149, 102292. [CrossRef]

59. Haq, F.; Seraphïm, J.; Medhekar, A. Branding Heritage Tourism in Dubai: A Qualitative Study. Adv. Hosp. Tour. Res. AHTR 2021, 782679. [CrossRef]

60. Campra, M.; Brescia, V.; Jafari-Sadeghi, V.; Calandra, D. Islamic countries and Maqasid al-Shariah towards the circular economy. The Dubai case study. Eur. J. Islam. Financ. 2021, 17, 4560. [CrossRef]

61. Darwish, M.A.A. The Effect of Artificial Intelligence in Smart Decision-Making in the UAE Government. Available online: https://www.eimj.org/uplode/images/photo/The_Effect_Of_Artificial_Intelligence_In_Smart_Decision-Making_In_The_ UAE_Government.pdf (accessed on 22 October 2021).

62. Elsayed, Y.A.; El-Sayed, S.H. The Impact of the Smart Modern Transportation on Urban Structure of the Cities. In Advanced Studies in Efficient Environmental Design and City Planning; Springer: Berlin/Heidelberg, Germany, 2021; pp. 601-610. [CrossRef]

63. Ali, G.M. A Deferred Model for Evaluating and Improving The Dubai Metro Train Security Management. Ph.D. Thesis, Cardiff Metropolitan University, Cardiff, UK, 2021. [CrossRef]

64. Wiedmann, F.; Schlosser, C. Urban Fabrics and the Future of Transport-Oriented Development in Gulf Cities. In Urban Challenges in the Globalizing Middle-East: Social Value of Public Spaces; Azzali, S., Mazzetto, S., Petruccioli, A., Eds.; Springer International Publishing: Cham, UK, 2021; pp. 153-169. [CrossRef]

65. Blayac, T.; Stéphan, M. Are retrospective rail punctuality indicators useful? Evidence from users perceptions. Transp. Res. Part Policy Pract. 2021, 146, 193-213. [CrossRef]

66. Poon, J.F.; Vickerman, R. Workshop 8: Beyond the farebox: Sustainable funding of public transport by better understanding service values. Res. Transp. Econ. 2020, 83, 100923. [CrossRef]

67. Benoliel, M.A.; Manso, M.; Ferreira, P.D.; Silva, C.M.; Cruz, C.O. “Greening” and comfort conditions in transport infrastructure systems: Understanding users' preferences. Build. Environ. 2021, 195, 107759. [CrossRef]

68. Woodburn, A. Rail network resilience and operational responsiveness during unplanned disruption: A rail freight case study. $J$. Transp. Geogr. 2019, 77, 59-69. [CrossRef]

69. Palmqvist, C.-W.; Olsson, N.; Hiselius, L. Delays for passenger trains on a regional railway line in Southern Sweden. Int. J. Transp. Dev. Integr. 2017, 1, 421-431. [CrossRef]

70. Palmqvist, C.-W.; Tomii, N. Overtakes and dwell time delays for Japanese commuter trains. In Proceedings of the 15th World Conference on Transportation Research, Mumbai, India, 26-31 May 2019.

71. Palmqvist, C.-W. Delays and Timetabling for Passenger Trains. Ph.D. Thesis, Lund University, Lund, Sweden, 2019.

72. Olsson, N.O.; Haugland, H. Influencing factors on train punctuality—Results from some Norwegian studies. Transp. Policy 2004, 11, 387-397. [CrossRef]

73. Olsson, N.; Økland, A.; Veiseth, M.; Stokland, Ø. Driftsstabilitet på Jernbaneverkets Nett-Årsaksanalyser 2005-2010, Punktlighets- og Regularitetsutviklingen, Gransking av Årsaker; SINTEF: Trondheim, Norway, 2010.

74. Nyström, B. Aspects of Improving Punctuality: From Data to Decision in Railway Maintenance. Ph.D. Thesis, Luleå Tekniska Universitet, Lulea, Sweden, 2008.

75. Tremblay, M. Sustainable Mobility Policy-2030: Transporting Québec Towards Modernity. In Proceedings of the 26th World Road Congress World Road Association, Abu Dhabi, United Arab Emirates, 6-10 September 2019.

76. Rama, D.; Andrews, J.D. System-Wide Assessment of Intervention Strategies for Railway Infrastructure; University of Nottingham: Nottingham, UK, 2014.

77. Lethanh, N.; Adey, B.T. A real option methodology to determine the optimal intervention windows for railway infrastructure. Comput. Railw. XIV Railw. Eng. Des. Optim. 2014, 135, 437.

78. Mohammadi, A.; El-Diraby, T. Toward user-oriented asset management for urban railway systems. Sustain. Cities Soc. 2021, 70, 102903. [CrossRef] 
79. Machado-León, J.L.; de Oña, R.; Baouni, T.; de Oña, J. Railway transit services in Algiers: Priority improvement actions based on users perceptions. Transp. Policy 2017, 53, 175-185. [CrossRef]

80. Tabti-Talamali, A.; Baouni, T. Public transportation in Algiers: Towards a new governance approach. Case Stud. Transp. Policy 2018, 6, 706-715. [CrossRef]

81. Larumbe, J. Measuring Customer Reservation Price for Maintenance, Repair and Operations of the Metro Public Transport System in Qatar. Sustainability 2021, 13, 11023. [CrossRef]

82. Yuan, H. Achieving Sustainability in Railway Projects: Major Stakeholder Concerns. Proj. Manag. J. 2017, 48, 115-132. [CrossRef]

83. De Paula, L.B.; Marins, F.A.S. Algorithms applied in decision-making for sustainable transport. J. Clean. Prod. 2018, 176, 1133-1143. [CrossRef] 